\title{
Suppression of Sprouting: An Early Function of NMDA Receptors in the Absence of AMPA/Kainate Receptor Activity
}

\author{
Shuh-Yow Lin and Martha Constantine-Paton \\ Department of Molecular, Cellular, and Developmental Biology, Yale University, New Haven, Connecticut 06520
}

\begin{abstract}
Electrophysiological studies have documented the existence of synapses showing only NMDA ionotropic glutamate receptor function that are therefore presumably "silent" at resting membrane potentials. Silent synapses are more prevalent in young than in older neurons, and NMDA receptor activity at such contacts may facilitate the appearance of functional AMPA receptors. However, it is uncertain whether such silent synapses actually have a function in young neurons independent of AMPA receptor induction. Using a newly characterized culture system for neurons from larval Xenopus tecta, we show that blocking NMDA receptors or preventing changes in intracellular free $\mathrm{Ca}^{2+}$ concentration with BAPTA AM significantly increases neurite sprouting and elongation in contacted but not in isolated neurons. Blocking AMPA/KA receptors or $\mathrm{Na}^{+}-$
\end{abstract}

Ionotropic glutamate receptors have been implicated in many stages of brain development. Thus, AMPA/kainate (AMPA/ $\mathrm{KA}$ ) receptors are initially expressed in the ventricular proliferative zone of the neocortex, where their activation decreases DNA synthesis and may initiate neuron differentiation (LoTurco et al., 1995). NMDA receptors, which have been implicated in neuron migration (Komuro and Rakic, 1993), appear only after young neurons leave the ventricular zone (LoTurco et al., 1991, 1995). Later during neuropil maturation, both AMPA/KA and NMDA receptor functions affect the morphology of postsynaptic cells (Mattson et al., 1988; Rocha and Sur, 1995), and NMDA receptor activity refines the pattern of afferent termination (Cline et al., 1987; Bear et al., 1990; Hahm et al., 1991).

Most recently, a significant proportion of young synapses in several brain regions have been reported to show NMDA but not AMPA receptor activity. Conversion of such pure NMDA receptor and therefore presumably silent synapses to mixed NMDA and AMPA receptor synapses can occur via NMDA receptor activity induced during experimental pairing of presynaptic activation and postsynaptic depolarization (Liao et al., 1995; Durand et al., 1996; Wu et al., 1996; Isaac et al., 1997). Thus, activation of NMDA receptors leading to increased AMPA receptor function might constitute a previously unrecognized step in synaptic maturation. However, it is not yet clear whether these early NMDA

\footnotetext{
Received Jan. 6, 1998; revised Feb. 25, 1998; accepted March 2, 1998.

This work was supported by National Institutes of Health Grant EY06039. We thank Judy Chou and Ella Vining for excellent technical assistance, Drs. Haig Keshishian, Paul Forscher, and Ann Cornell-Bell for helping with $\mathrm{Ca}^{2+}$ imaging, Drs. C. Barnstable and R. Jahn for gifts of antibodies, and Drs. Sandra Aamodt and Haig Keshishian for valuable comments on this manuscript.

Correspondence should be addressed to Dr. Shuh-Yow Lin, Department of Molecular, Cellular, and Developmental Biology, KBT, P.O. Box 208103, New Haven, CT 06520.

Copyright (C) 1998 Society for Neuroscience $\quad 0270-6474 / 98 / 183725-13 \$ 05.00 / 0$
}

dependent action potentials does not mimic this effect. Moreover, in these young neurons, NMDA receptor-dependent $\mathrm{Ca}^{2+}$ responses to glutamate measured with confocal fluo-3 imaging are retained during AMPA/KA receptor blockade. The data suggest that many of the young contacts in these cultures are active even though they use only NMDA ionotropic glutamate receptors. Calcium influx through the NMDA receptor at these contacts seems to reduce neurite motility. This effect should lead to the accumulation of glutamatergic inputs on NMDA receptor-expressing dendrites, which could facilitate the onset of AMPA/KA receptor function and the action potentialdependent phase of synaptogenesis.

Key words: neurite sprouting; activity-dependent; NMDA receptor; silent synapse; $\mathrm{Ca}^{2+}$; SNAP-25 receptors are normally active or whether their activation has any significant effect on neuron morphology or on the development of circuitry before the appearance of AMPA current.

In this report, a dissociated Xenopus tectal neuron culture system is characterized and used to study the function of NMDA receptors during the earliest stages of circuit formation. Our data demonstrate a pronounced sprouting effect of NMDA receptor antagonists before AMPA/KA currents or action potential activity play a significant role in activating nascent circuitry or removing the NMDA receptor $\mathrm{Mg}^{2+}$ block. These findings suggest that silent synapses are not silent. Instead, one of their earliest functions seems to be reducing neurite motility, and we propose that it is this event that allows synaptogenesis to proceed.

\section{MATERIALS AND METHODS}

Xenopus dissociated tectal cultures. Tectal lobes from anesthetized $(0.5 \%$ topical MS 222) Xenopus laevis tadpoles (stages 55-60; Nieuwkoop and Faber, 1967) were dissected into $\mathrm{Ca}^{2+}$ - and $\mathrm{Mg}^{2+}$-free Steinberg's solution (NCM-EDTA-HBSS with $58 \mathrm{~mm} \mathrm{NaCl}, 0.7 \mathrm{~mm} \mathrm{KCl}, 4.6 \mathrm{~mm}$ HEPES, and 0.4 mM EDTA) and then transferred to digestion solution for $30 \mathrm{~min}$ (NCM-EDTA-HBSS with trypsin and BSA at 1.3 and 3 $\mathrm{mg} / \mathrm{ml}$, respectively). After digestion, centrifugation, and addition of trypsin inhibitor at $1 \mathrm{mg} / \mathrm{ml}$, tissue was transferred to culture medium with DNase-I at $0.1 \mathrm{mg} / \mathrm{ml}$ and was triturated with a fire-polished Pasteur pipette. After centrifugation to remove cellular debris, isolated tectal cells were resuspended in different amounts of culture medium to achieve the desired cell density (low-density cultures, $\sim 200 \mathrm{cells} / \mathrm{cm}^{2}$; highdensity cultures, $\sim 1000$ cells $/ \mathrm{cm}^{2}$ ). Coverslips used for culturing were coated with poly-L-lysine in $0.1 \mathrm{M}$ boric acid, $\mathrm{pH} 8.3$, or water. Culture medium was composed of $50 \% \mathrm{~L}-15,10 \%$ fetal calf serum, $2 \%$ penicillin and streptomycin, and $0.1 \%$ gentamycin. The ion concentration of this medium was $\mathrm{Na}^{+}, 85 \mathrm{mM} ; \mathrm{K}^{+}, 3.3 \mathrm{~mm} ; \mathrm{Mg}^{2+}, 2 \mathrm{mM}$; and $\mathrm{Ca}^{2+}, 1.67 \mathrm{mM}$; the medium was buffered by $2 \mathrm{mM} \mathrm{NaHCO}_{3}$ and $20 \mathrm{~mm}$ HEPES. Serum helps to maintain longer cell survival. Similar effects of AP-5 were observed in cultures without serum. Cultures were incubated at $18^{\circ} \mathrm{C}$ and could be maintained for at least $10 \mathrm{~d}$.

Immunocytochemistry. After fixation in $4 \%$ paraformaldehyde with 
0.12 M sucrose, cultures were permeabilized with $0.3 \%$ Triton X-100 for 3-5 min. Nonspecific binding was blocked for $2 \mathrm{hr}$ with $3 \%$ BSA or $1.5 \%$ goat serum. Primary antibodies [anti-tubulin, 1:100; anti-synaptosomalassociated protein (SNAP)-25, 1:500; anti-synaptophysin, 1:400; antiglutamate, 1:1000; and anti-GABA, 1:50] were applied for $2 \mathrm{hr}$ at room temperature or overnight at $4^{\circ} \mathrm{C}$. Fluorophor-conjugated secondary antibody was used to localize specific antigens by either conventional epifluorescence or confocal microscopy. Differential interference contrast (DIC) and fluorescent images were captured by a Cohu 4915 CCD camera and were digitized by a frame grabber-equipped personal computer or Macintosh. Images were stored on an OMDR disk or as binary files in the computer. Some images were processed with NIH Image to enhance contrast and sharpness. Macros for controlling the light shutter, camera frame integration, and OMDR operations were developed by S.-Y. Lin. NIH Image was written by W. Rosband at the National Institutes of Health. In the comparison of immunocytochemical staining, the gain, black level, and the number of video frames integrated were maintained throughout experiments. Pseudo color and composite digital images were produced under Adobe PhotoShop.

Morphological analysis of cells in culture. A region $670 \mu \mathrm{m}$ in diameter at the center of culture coverslips was marked, and the same $0.3 \mathrm{~mm}^{2}$ region in this field was photographed each day through a Nikon Diaphot equipped with phase-contrast optics at 1,2 , and $3 \mathrm{~d}$ in vitro (DIV). Morphological analyses were performed under the National Institutes of Health Image program, with several customized macros to generate working images and organize the analysis. PhotoShop plug-ins developed by Dr. J. Russ at the University of North Carolina were used to overlay square grids onto the images and count dots, which were placed to represent cell number, neurite ends, and grid crossings. Data were then normalized by cell number before calculation of averages and SEs. One-way ANOVA was used in all morphometric comparisons.

Calcium imaging. Calcium imaging was performed using an MRC-500 confocal microscope equipped with an argon laser and a $40 \times$ Zeiss Plan-Apo objective (numerical aperture, 1.0). This was upgraded to an MRC-600 during the course of these experiments. Tectal cells were loaded with fluo-3 (5 $\mu \mathrm{M}$ fluo-3 in DMSO and $3 \mu \mathrm{M} \mathrm{F}-127$ in culture medium) for 30-35 min and washed with frog saline solution (FSS) (Cline and Tsien, 1991): $100 \mathrm{~mm} \mathrm{NaCl}, 2 \mathrm{~mm} \mathrm{KCl,} 2.5 \mathrm{~mm} \mathrm{CaCl}_{2}, 3 \mathrm{~mm}$ $\mathrm{MgCl}_{2}, 5 \mathrm{~mm}$ glucose, and $5 \mathrm{mM}$ HEPES. Coverslips containing the cells were mounted in a customized chamber (Yale medical school machine shop) and perfused with FSS for 15 min. Fluorescence was excited by 488 $\mathrm{nm}$ emission of the argon laser. For stimulation of NMDA receptors, 100 $\mu \mathrm{M}$ NMDA in $\mathrm{Mg}^{2+}$-free FSS containing $5 \mu \mathrm{M}$ glycine was perfused through the chamber for $80 \mathrm{sec}$, followed by FSS for $3 \mathrm{~min}$. In most experiments, the quantitative data were collected in fields from three to four different cultures representing at least two different dissociations. Eight-bit gray scale images were collected at 2-10 sec intervals and stored on an OMDR disk for later analysis. A macro developed by Dr. Haig Keshishian controlled batch processing of time-lapse OMDR recordings on the MRC-500/600.

Fluo-3 fluorescence intensity changes were estimated by measuring the pixel value of images. NIH Image macros and programs developed by S.-Y. Lin were used for marking multiple cells and for recording measurements from the same cells in multiple frames from the OMDR images. Cells with fluorescent response saturating the eight bit gray scale level were not measured. Intracellular free $\mathrm{Ca}^{2+}$ concentration changes $\left(\Delta\left[\mathrm{Ca}^{2+}\right]_{\mathrm{i}}\right)$ were estimated as $\Delta F / F 0$, where $\Delta F$ is fluorescent intensity of the response minus the baseline intensity and $F 0$ was derived from the averaged intensity of the first 10-20 frames minus the background in the cell-free region (Kao et al., 1989). This method cancels differences in initial dye loading, but it is susceptible to changes in cell volume and photobleaching, which can change the intracellular dye concentration and subsequently change the baseline fluorescent intensity. Therefore, cells that changed their fluorescent intensity $>10 \%$ by the end of an experiment were eliminated from further analyses.

SDS-PAGE and Western blotting. Protein samples were collected and homogenized in Laemmli buffer (Laemmli, 1970) with a cocktail of protease inhibitors (Boehringer Mannheim, Indianapolis, IN) and were boiled for $3 \mathrm{~min}$ at $90^{\circ} \mathrm{C}$. Protein concentration was determined with the Bio-Rad DC kit (Hercules, CA). DTT and bromphenol blue were added to the protein samples after concentration was determined. Equal amounts of protein $(5-10 \mu \mathrm{g})$ were loaded onto each lane of $10 \%$ polyacrylamide gels. After electrophoresis, separated proteins were transferred to nitrocellulose paper, and the transfer efficiency was estimated by Ponceau-S staining. Nitrocellulose paper with protein was then incubated with $3 \%$ gelatin for $1.5 \mathrm{hr}$ to block nonspecific binding sites, and primary antibodies were applied (anti-SNAP-25, 1:1000; antisyntaxin, 1:500; and anti-tubulin, 1:250) for $1.5 \mathrm{hr}$, followed by extensive washing with Tris-buffered saline with $0.1 \%$ Tween 20 . A peroxidaseconjugated secondary antibody was used at 1:3000 to 1:5000 dilution for $30 \mathrm{~min}$, followed by three washes. Specific protein bands were visualized with $\mathrm{x}$-ray film using the enhanced chemiluminescence method according to the recommendations of the manufacturer (Amersham, Arlington Heights, IL). In initial Western blotting, entire lanes were reacted with single antibodies to ensure specificity and nondegradation of protein (single band). Subsequently the nitrocellulose papers were cut to isolate particular molecular weight ranges so that multiple antigens could be followed in the small protein samples available.

Protein quantification was accomplished by digitizing the x-ray film images with a Dage Nuvicon video camera and a frame grabber in Macintosh. The integrated peak optical density (OD) value of an entire protein band was measured by calibrating the pixel values to external OD standards (Kodak). Usually, a serial dilution of protein derived from one treatment group was included in each PAGE gel to verify that the signal was in the linear range of the detection system. Because absolute protein amount remains unknown, data are presented as a comparison between treated and control groups. National Institutes of Health Image and the macro Gel Macro in NIH Image were used to measure the integrated peak OD value.

Materials and antibodies. Xenopus tadpoles were purchased from $X e$ nopus I. D,L-2-Amino-5-phophonovalerate (AP-5) was from Tocris. 6-Cyano-7-nitroquinoxaline-2,3-dione (CNQX) was from Research Biochemicals (Natick, MA). TTX was from Calbiochem (La Jolla, CA). Fluo-3, BAPTA AM, and FM 1-43 were from Molecular Probes (Eugene, OR). L-15 medium and fetal calf serum were from Gibco. All other chemical regents were purchased from Sigma (St. Louis, MO). Anti-SNAP-25 monoclonal antibody was from Sternberger. Anti-glutamate and anti-GABA antibodies were from Sigma. Anti-tubulin and anti-glutamic acid decarboxylase (anti-GAD) monoclonal antibodies were from Boehringer Mannheim. Peroxidase-conjugated antibodies were from Jackson Labs. Anti-syntaxin and anti-NMDA R1 subunit were gifts from Drs. C. Barnstable and R. Jahn (Yale Medical School), respectively.

\section{RESULTS}

\section{Characterization of tectal cell cultures}

Previous work on dissociated tadpole tectal cultures has identified a population of small round cells with fine processes as neurons on the basis of staining with the LINC monoclonal antibody, which recognizes axons in the leopard frog Rana pipiens (Steen et al., 1989). That study also morphologically identified several other cell types, only one of which had a definitively non-neuronal, fibroblast-like shape. We found the same morphological types in the larval Xenopus tectal cells used in this study and immunocytochemically characterized the neurons in terms of the excitatory and inhibitory amino acids glutamate and GABA, respectively. After $6 \mathrm{~d}$ in vitro, $71 \%$ of the cells with nonfibroblast morphology in the cultures were positive for glutamate antibody $(n=146$ cells from two cultures), and $13 \%$ of the nonfibroblast-like cells were positive for GABA antibody ( $n=144$ cells from two cultures). The specificity of the GABA antibody was confirmed by doublelabeling cultures with a mouse antibody against GAD. Essentially all of the GABA-positive cells in double-stained cultures also showed anti-GAD staining. Staining for anti-glial fibrillary acidic protein (GFAP), we identified $3 \%$ of the population with a bipolar morphology and unusually thick processes as glia. However, it is likely that the glial population is somewhat higher, because not all astrocytes can be stained with anti-GFAP and numerous differentiating oligodendrocytes are found in intact tadpole tecta (Steen et al., 1989). The cell counts presented in this report include only cells with nonfibroblast-like morphology. Based on the immunocytochemical characterization above, GABAergic and glutamatergic neurons occur in these cultures in 


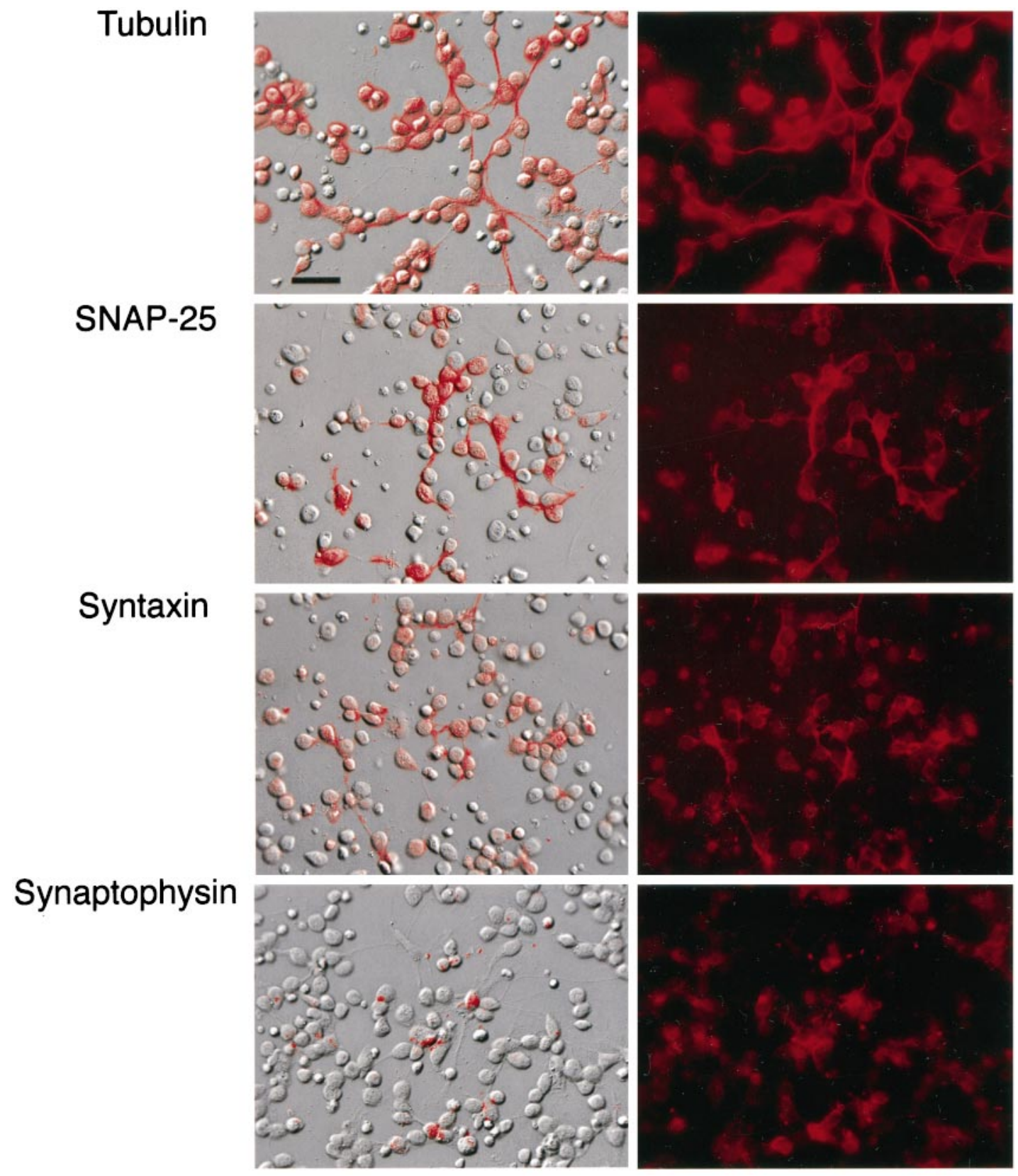

Figure 1. $\beta$-Tubulin, SNAP-25, syntaxin, and synaptophysin immunostaining in tectal cultures. The micrographs on the right illustrate the typical staining pattern in these cultures after 4 DIV. The left panels are a composite of the DIC images with fluorescence staining of the same field. Scale bar, $20 \mu \mathrm{m}$.

a ratio of $\sim 1: 6$. This proportion of GABAergic cells is similar to that observed in young cultures of mammalian superior colliculus (Warton et al., 1990).

To facilitate analyses of neurite growth and synapse formation, we characterized staining in tectal cultures with antibodies to SNAP-25, syntaxin, and synaptophysin and compared these with cytoskeletal staining using anti- $\beta$-tubulin antibody (Fig. 1$)$. Some of the somata and processes in these cultures were heavily stained with SNAP-25 and syntaxin antibodies (Fig. 1). Most of the SNAP-25 staining was concentrated in the contact area between cell bodies, where numerous neurites and small branches fasciculated. In some cells, heavy SNAP-25 staining could be found in the tips of short branches extending directly from the soma. As in previous reports using mammalian cells (Osen-Sand et al., 1993),
SNAP-25 appeared to stain the axon compartment as well as contacts in young tectal neurons. Syntaxin staining was similar to SNAP-25 staining except that the signal was weaker. The relatively low density of punctate staining seen with antibodies raised against the frog synaptic vesicle protein synaptophysin was similar to that seen in young cultures of neonatal mammalian neurons (Fletcher et al., 1994).

We found no markers that were selective for the dendritic compartment of cultured frog neurons. Antibodies against mammalian microtubule-associated protein 2 (MAP 2; antibody clones, AP18 and AP20 from NeoMarker, HM-2 from Sigma, and SMI 52 from Sternberg) and against sprouting Drosophila neurons (DMAP 55, from D. Carr) failed to react or reacted nonspecifically in tectal sections or cultures. DMAP 55 antibody was 
later found to recognize sprouting dendrites and axons in mammalian brain (Alcantara et al., 1995). It is also possible that axonal and dendritic compartments may not be distinct in young tectal neurons, because axons in vivo generally arise from the proximal regions of the dendritic tree (Katz and Constantine-Paton, 1988).

\section{$\mathrm{Ca}^{2+}$ response to exogenous and endogenous glutamate}

Most frog tectal neurons express both AMPA/KA and NMDA glutamate receptors at the synapses that receive inputs from the retina and other tectal neurons (Hickmott and ConstantinePaton, 1993). Fluo-3 was used to examine NMDA and AMPA/KA receptor activity in cultured tectal neurons by monitoring changes in $\Delta\left[\mathrm{Ca}^{2+}\right]_{\mathrm{i}}$ in response to applied glutamate or NMDA and then by comparing these responses with responses to agonist plus antagonist. The results of these experiments for tectal neurons 1-2 DIV are presented in Figure 2. The trace of $\Delta F / F O$ on the left in Figure $2 A$, made from a cell in $3 \mathrm{~mm} \mathrm{Mg}^{2+}$, illustrates typical decreases in the $\mathrm{Ca}^{2+}$ response to glutamate with either $200 \mu \mathrm{M}$ AP-5 or $20 \mu \mathrm{M}$ CNQX added to the stimulating solution. The response to agonist alone was tested before and after presentation of the solutions containing receptor blockers in all of these experiments. The two agonist responses were then averaged to compare with the response of agonist plus antagonist. AP-5 reduced the $\Delta\left[\mathrm{Ca}^{2+}\right]_{\mathrm{i}}$ response to $39.3 \%( \pm 8$ $\mathrm{SEM}$ ) of the response to glutamate alone, whereas surprisingly CNQX had a smaller effect, reducing the response to only $59.1 \%$ ( $\pm 3.8 \mathrm{SEM}$ ) of the response to glutamate alone. In the graph on the right of Figure $2 A$, the relative effects of CNQX and of AP-5 on the $\mathrm{Ca}^{2+}$ response to glutamate are plotted against each other for each of the 27 neurons examined. Most points fall above the diagonal, illustrating that AP-5 had a considerably larger effect than did CNQX on decreasing the $\mathrm{Ca}^{2+}$ response to glutamate in the majority of these young tectal neurons. Such a result was unexpected; if AMPA/KA channel function is necessary to remove the $\mathrm{Mg}^{2+}$ blockade on the NMDA channel in these neurons, then blocking AMPA/KA receptors with CNQX should eliminate both the $\mathrm{Ca}^{2+}$ influx initiated by the AMPA channels and the $\mathrm{Ca}^{2+}$ influx through NMDA receptors.

To determine whether the $\mathrm{Ca}^{2+}$ response to glutamate remaining in the presence of CNQX was in fact mediated by NMDA receptor channels, we next applied glutamate with both CNQX and AP-5. The $\Delta F / F 0$ trace on the left in Figure $2 B$ illustrates that the simultaneous application of these two antagonists completely eliminated the response to glutamate. The histogram on the right in Figure $2 B$ summarizes these data for all 47 cells tested and shows that complete elimination of the glutamate response by CNQX plus AP-5 was seen in the vast majority of tectal neurons.

One possible explanation for this surprising observation that NMDA receptors function in the absence of AMPA receptors is that young tectal neurons do not have a typical $\mathrm{Mg}^{2+}$-dependent voltage blockade. However, Figure $2 C$ shows that this is not the case. The trace on the left of the figure shows a typical response of a tectal neuron to $100 \mu \mathrm{M}$ NMDA presented in $0 \mathrm{Mg}^{2+}$. This response can be blocked by $3 \mathrm{mM} \mathrm{Mg}^{2+}$. For the 24 neurons tested in this way, only $2.6 \%( \pm 0.61 \mathrm{SEM})$ of $\Delta\left[\mathrm{Ca}^{2+}\right]_{\mathrm{i}}$ induced by NMDA was maintained in the presence of $\mathrm{Mg}^{2+}$. Thus, the NMDA receptors expressed on these neurons have a normal $\mathrm{Mg}^{2+}$ sensitivity. These data also eliminate the possibility that the neurons are tonically depolarized and therefore insensitive to $\mathrm{Mg}^{2+}$ blockade.

The histogram in Figure $2 D$ summarizes all of the data on blocker-induced decreases in $\mathrm{Ca}^{2+}$ response to glutamate. The experiments indicate that depolarization sources other than AMPA/KA receptor-mediated currents must be present to allow the NMDA receptor to respond to glutamate in these young tectal neurons.

Under phase-contrast or DIC optics, fields of young, lowdensity tectal cells could be grouped into contacted or isolated populations with neuron-like morphology. We characterized the noncontacted cells further with the intent of using them as internal controls for the effects of glutamate released by endogenous contacts. To eliminate the possibility that the noncontacted population represented non-neuronal or unhealthy cells, we used $\mathrm{Ca}^{2+}$ imaging to examine the response of both contacted and noncontacted cells to NMDA in the absence of $\mathrm{Mg}^{2+}$. Of 75 cells examined at $1 \mathrm{DIV}$, only seven cells were unresponsive to NMDA $(9.3 \%)$. Of these cells, three were isolated, and four were in contact with other cells. At 3 DIV, 92 cells were assayed. Ten cells $(10.8 \%)$ showed no response. Nine of these cells were connected to other cells, and only one cell was isolated. Thus, most isolated cells in young tectal cell cultures are healthy, NMDA receptorexpressing neurons.

Several previous investigators have used $0 \mathrm{Mg}^{2+}$ plus glycine to induce a $\mathrm{Ca}^{2+}$-dependent and TTX-sensitive release of endogenous glutamate that can be detected by NMDA receptors in cultured hippocampal neurons (Abele et al., 1990; Verderio et al., 1995). This $\mathrm{Mg}^{2+}$-inducible release of glutamate is inhibitable by $\mathrm{Ca}^{2+}$ channel blockers and by botulinum toxin, suggesting that the mechanism of release is similar to conventional neurotransmitter release (Verderio et al., 1995). Consequently, we have used $0 \mathrm{Mg}^{2+}$ plus glycine in the tectal cultures to determine whether contact sites in these cultures released glutamate sufficient to activate postsynaptic receptors despite the absence of robust synaptophysin staining. Figure 3 shows glutamate release detected by monitoring $\Delta\left[\mathrm{Ca}^{2+}\right]_{\mathrm{i}}$ in response to $0 \mathrm{Mg}^{2+}$ plus glycine at 4 DIV. In our experiments most neurons were unable to generate responses after several exposures to $0 \mathrm{Mg}^{2+}$ plus glycine, indicating that we were depleting a limited glutamate pool. Consequently, for quantitative analysis of responding cells, only data from cells that showed a robust $\Delta\left[\mathrm{Ca}^{2+}\right]_{i}$ in response to 0 $\mathrm{Mg}^{2+}$ plus glycine at both the beginning and the end of the experimental run were used. Thirty-five of 102 monitored tectal cells $(34 \%)$ showed increases and/or oscillations in internal $\mathrm{Ca}^{2+}$ induced by the $\mathrm{Mg}^{2+}$-free solution, indicating that approximately a third of the population could be driven from their glutamatergic contacts. Twenty-five of these cells were exposed to the $\mathrm{Mg}^{2+}$ free solution in the presence of AP-5. In all 25 neurons, the $\mathrm{Ca}^{2+}$ response was completely eliminated, indicating that it was initiated by NMDA receptor activity and that neither AMPA/KA nor metabotropic receptor functioning alone could produce a detectable $\mathrm{Ca}^{2+}$ response at neuron-neuron contacts. The ability of TTX to block the $\mathrm{Ca}^{2+}$ response to $\mathrm{Mg}^{2+}$ and glycine was tested in the remaining 10 responsive neurons. Unlike the previous work on cultured hippocampal neurons, TTX was ineffective in blocking the NMDA receptor-mediated response. In one final experiment, $\mathrm{Ca}^{2+}$ responses to $0 \mathrm{Mg}^{2+}$ plus glycine were monitored in a field of neurons, and then the membranes of these neurons were visualized by perfusion with $1.5 \mu \mathrm{g} / \mathrm{ml}$ of FM 1-43. In this field all nine neurons responding to $0 \mathrm{Mg}^{2+}$ plus glycine were contacted, and none of the isolated cells $(n=3)$ responded to the $\mathrm{Mg}^{2+}$-free plus glycine solution even though all 12 cells responded to NMDA in $0 \mathrm{Mg}^{2+}$. Thus, in these tectal neuron cultures, there is the potential for endogenous glutamate release 
A

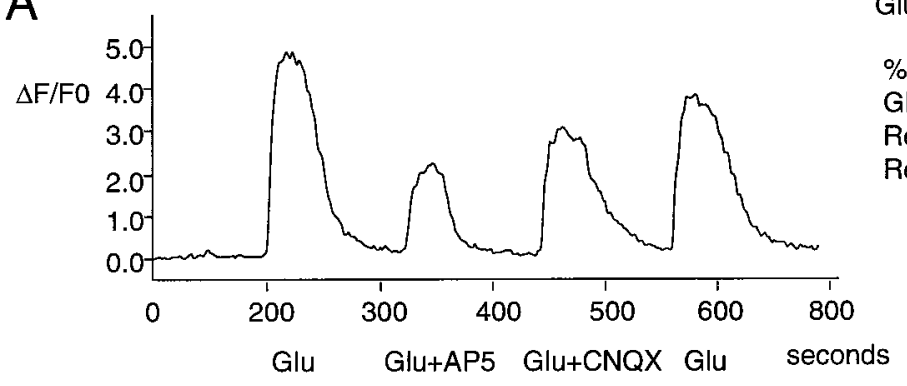

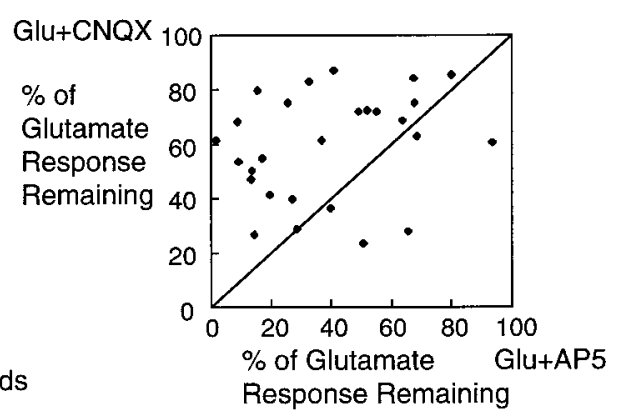

Response Remaining

B
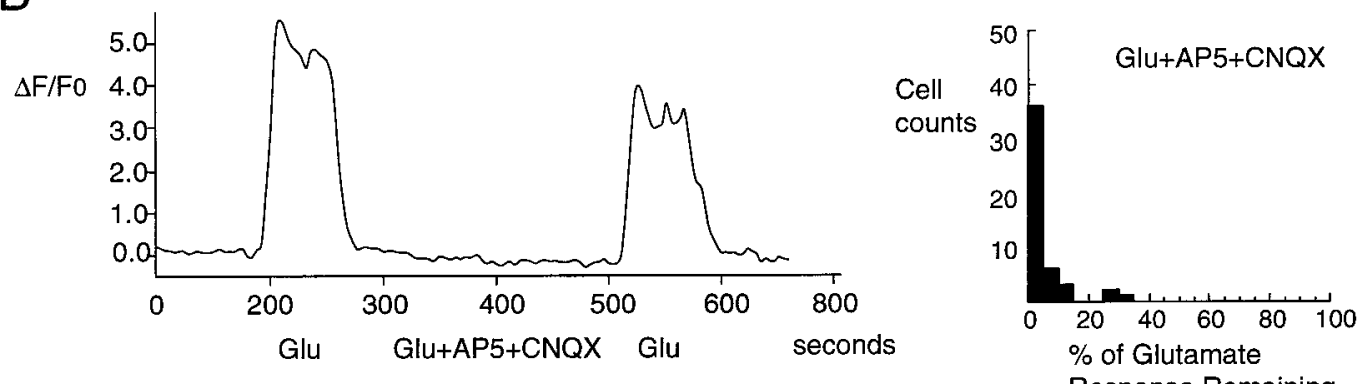

C

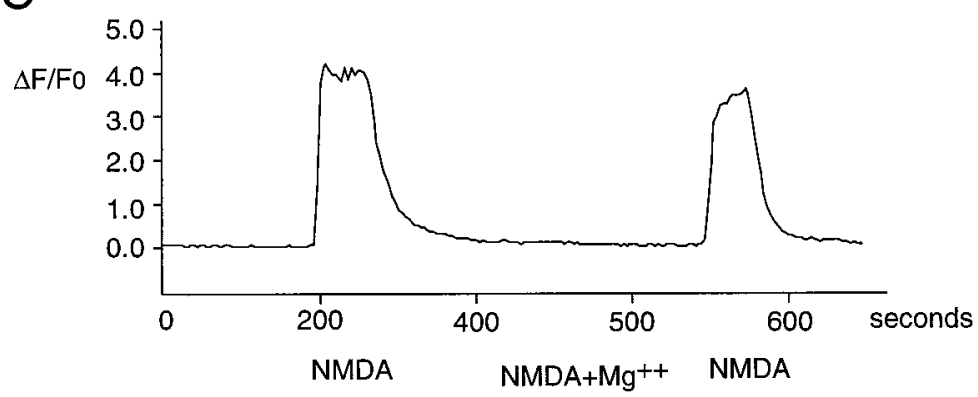

D

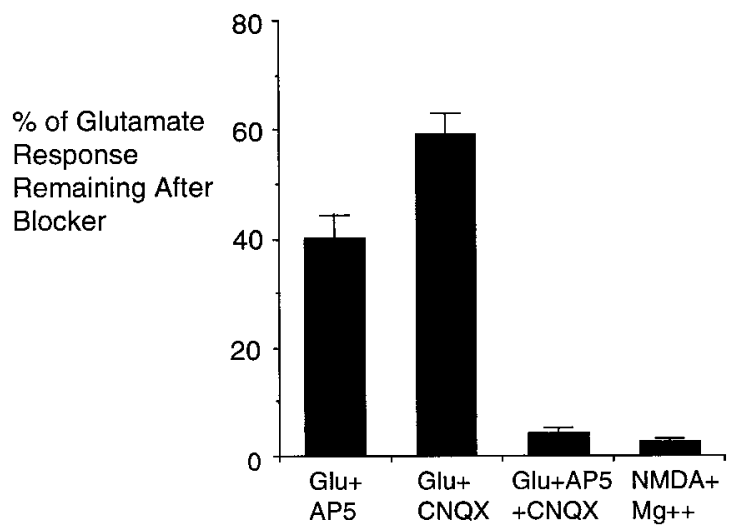

Figure 2. Changes in $\Delta\left[\mathrm{Ca}^{2+}\right]_{\mathrm{i}}$ in response to glutamate receptor stimulation are mediated primarily by NMDA receptor functioning independent of AMPA/KA receptor functioning. $A$, A typical $\Delta\left[\mathrm{Ca}^{2+}\right]_{\mathrm{i}}(\Delta F / F 0)$ in response to $20 \mu \mathrm{M}$ glutamate in the presence of $3 \mathrm{~mm} \mathrm{Mg}{ }^{2+}$ is reduced more by AP-5 than by CNQX. $B$, Addition of AP-5 plus CNQX abolishes the $\Delta\left[\mathrm{Ca}^{2+}\right]_{\mathrm{i}}$ in response to glutamate in most tectal neurons, indicating that the Ca ${ }^{2+}$ response remaining in the presence of CNQX is mediated by the NMDA receptor. $C$, The $\Delta\left[\mathrm{Ca}^{2+}\right]_{\mathrm{i}}$ in response to $100 \mu \mathrm{M}$ NMDA is blocked by including $3 \mathrm{mM} \mathrm{Mg}^{2+}$ in the solution $(n=24)$, indicating that despite their ability to operate in the absence of AMPA/KA receptors, NMDA channels on tectal neurons have a normal $\mathrm{Mg}^{2+}$ blockade. $D$. Histogram summarizes the reduction in agonist-induced $\Delta\left[\mathrm{Ca}^{2+}\right]_{\mathrm{i}}$ in the presence of different ionotropic channel blockers. The percent of the glutamate response remaining with AP-5 in the presence of glutamate $(n=34$ cells), with CNQX in the presence of glutamate $(n=34$ cells), with CNQX plus AP-5 in the presence of glutamate $(n=47$ cells), and with NMDA in the presence of 3 mM $\mathrm{Mg}^{2+}(n=24$ cells $)$ is shown. Error bars represent SEM. All the solutions contained $1 \mu \mathrm{M}$ TTX. 
A
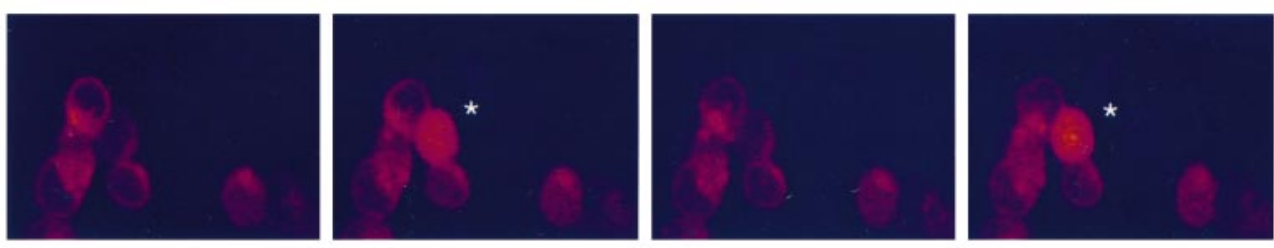

$0 \mathrm{Mg}++$, glycine \& AP5

$0 \mathrm{Mg}++$, glycine

$0 \mathrm{Mg}++$, glycine

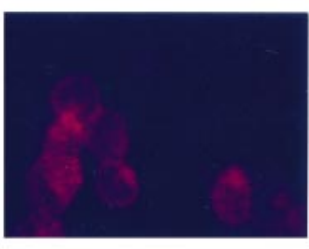

FSS

B
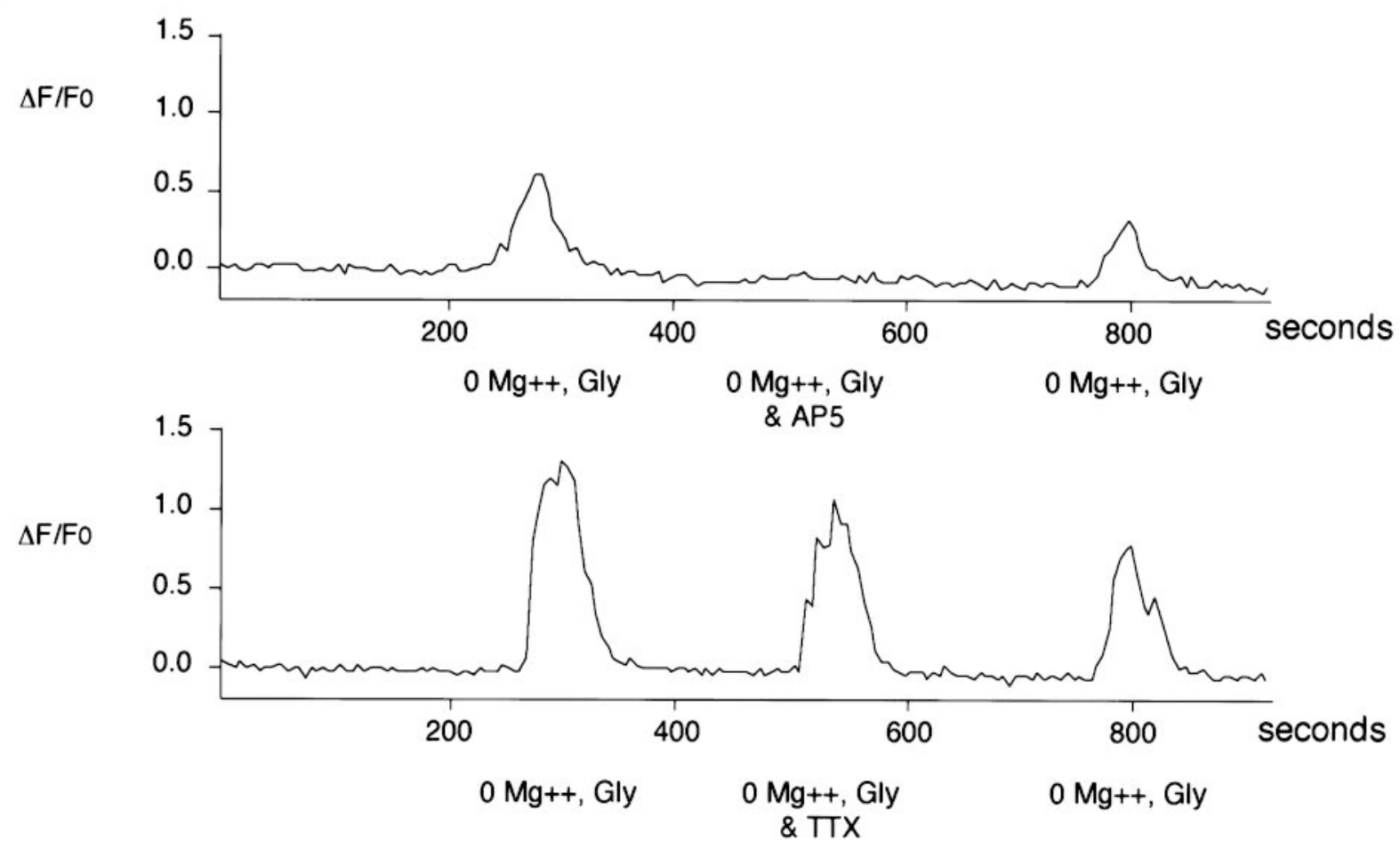

Figure 3. Changes in $\left[\mathrm{Ca}^{2+}\right]_{\mathrm{i}}$ induced by $0 \mathrm{Mg}^{2+}$ plus glycine reveal endogenous glutamate release. $A$, Frames showing fluo-3 confocal images of a contacted cell at 4 DIV (asterisks) after endogenous glutamate release induced by FSS with $0 \mathrm{Mg}^{2+}$ and supplemented with glycine. The perfusion medium used is shown below each image. $B$, Traces representing $\Delta\left[\mathrm{Ca}^{2+}\right]_{\mathrm{i}}$ in response to perfusion with $0 \mathrm{Mg}^{2+}$ plus glycine FSS in the presence of AP-5 or TTX. AP-5 completely abolishes the response to $0 \mathrm{Mg}^{2+}$ with glycine (top). TTX has a negligible effect on this response (bottom). The results indicate that the response to endogenous glutamate release is mediated by NMDA receptors and that amplification of glutamate release by circuit activity is not necessary to produce the response.

and activation of glutamate receptors at sites of neuron-neuron contact even though action potentials probably play a negligible role in inducing release at these young synapses. This lack of TTX effect in our cultures is probably attributable to immaturity. A similar lack of action potential-evoked synaptic currents has recently been documented electrophysiologically in young cultures of fetal hippocampal neurons (Basarsky et al., 1994).

NMDA receptor antagonists AP-5 and MK-801, but not CNQX or TTX, increase sprouting of tectal neurons

The preceding experiments document NMDA receptor function with minimal or no AMPA receptor function under two unnatural conditions: (1) $0 \mathrm{Mg}^{2+}$ solution with glutamate released endogenously but simultaneously at numerous contacts or (2) normal $\mathrm{Mg}^{2+}$ concentration with bath-applied agonist that can activate both synaptic and nonsynaptic receptors. To determine whether these receptors had a discernible function that could influence subsequent development under more natural conditions, we studied the morphological responses of tectal cultures to chronic treatments designed to perturb synaptic activity. Freshly dissociated low-density cultures were treated with $200 \mu \mathrm{M}$ AP-5, $1 \mu \mathrm{M}$ MK-801, $20 \mu \mathrm{M}$ CNQX, or $1 \mu \mathrm{M}$ TTX. Neurite growth and sprouting as well as cell survival were evaluated quantitatively in the same fields over the following $3 \mathrm{~d}$ as illustrated in Figures 4 and 5. Two morphological indices were used to quantify neurites. The number of neurite endings per cell estimated neurite initiation and branching (Fig. 5A), and neurite grid crossings per cell soma provided a rough estimate of the amount of process outgrowth. 
Control

Day 1

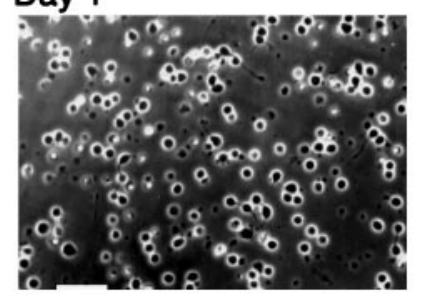

Day 2

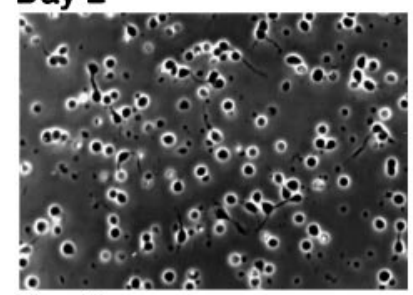

Day 3

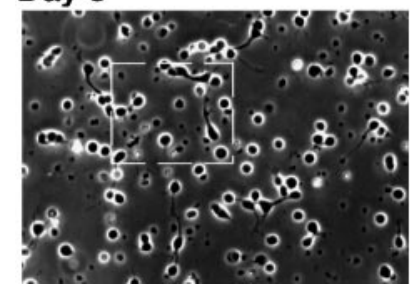

AP5
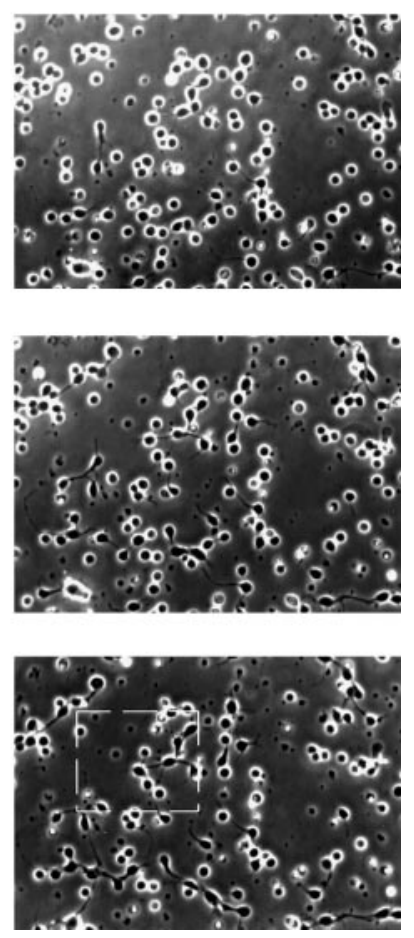

Figure 4. Representative changes in the same fields of tectal cells over the first 3 DIV for control and AP-5-treated low-density cultures. White rectangles indicate the fields enlarged in Figure $5 A$ (left) and $B$ (right). Only dark somata with bright halos are vital cells. Scale bar, $20 \mu \mathrm{m}$.

The histograms summarizing these morphological analyses are presented in Figure 6. AP-5 treatment increased sprouting of contacted cells by the end of the first day in culture (1 DIV; $p<$ 0.05 ; Fig. $6 A$ ), and this became more pronounced by 2 DIV ( $p<$ $0.01)$. Effects of MK-801 on neurite sprouting were first detected at 2 DIV $(p<0.01)$. Effects on grid crossings for both AP-5- and MK-801-treated cultures were first detected at 2 DIV $(p<0.01$; Fig. $6 B$ ). In contrast to the cultures treated with NMDA receptor antagonists, no significant differences from control in neurite sprouting or grid crossings were seen in the cultures treated with CNQX or TTX (Fig. $6 A, B$ ). Accurate neurite quantification was not possible on subsequent days in culture or in higher density cultures because of increased neurite density. However, effects of AP-5 were qualitatively apparent in cultures plated at higher densities and maintained for longer periods (Fig. 5B). These older cultures were used for biochemical assays.

The question of whether the repression of neurite sprouting and elongation resulted from glutamate released endogenously at cell-cell contacts was addressed using the same fields in which neurites of contacted cells were assayed. If effective levels of glutamate were freely diffusing in culture medium, then in the presence of NMDA receptor antagonist, isolated neurons in these fields should show an increase of neurite sprouting similar to that seen in the contacted neurons. The neurite tips per cell supported by isolated cells in all treatment groups were generally higher than were the neurite tips per cell in the contacted cells of the same fields (compare Fig. $6 A$ with $C$ ). However, at all three time points, there was no significant difference in sprouting between isolated cells in control and in either AP-5- or MK-801treated cultures. Thus, isolated neurons sprout more than con-

tacted neurons, and sprouting in isolated neurons is unresponsive to ionotropic receptor antagonists or blockade of $\mathrm{Na}^{2+}$. dependent action potentials. These results are internally consistent with each other, and both support the hypothesis that NMDA receptors function to suppress sprouting independent of AMPA/KA receptors in response to the endogenous spontaneous release of glutamate at neuron-neuron contacts.

The same fields of cells were also evaluated for differential cell survival, because activation of glutamate receptors can be toxic to cells (Choi, 1988). The only treatment that decreased cell survival was MK-801, and this decrease was not observed until 3 DIV (Fig. 6D). At this same time point, CNQX-treated cultures showed increased cell survival, providing the first indication of significant AMPA receptor function. Nevertheless, these data indicate that neurite sprouting or elongation is not consistently associated with increased cell survival.

\section{BAPTA mimics AP-5's effects on neurite sprouting}

To establish that $\Delta\left[\mathrm{Ca}^{2+}\right]_{\mathrm{i}}$ mediated by NMDA receptor activation is the parameter responsible for the suppression of sprouting, we used BAPTA to buffer changes in cytoplasmic $\mathrm{Ca}^{2+}$ concentrations in sets of cultures and compared sprouting in these cultures with controls and with cultures treated with AP-5 (Fig. 7). This analysis was possible because loading BAPTA into these cells was unlikely to affect endogenous glutamate release for two reasons. First, as indicated above, the glutamate release responsible for NMDA receptor activation in these cultures is primarily spontaneous and thus independent of transient $\mathrm{Ca}^{2+}$ increases at presynaptic terminals (Katz and Miledi, 1969; Dale and Kandel, 1990; Adler et al., 1991; Tanabe and Kijima, 1992). Second, at the frog neuromuscular junction, loading $100 \mu \mathrm{M}$ BAPTA AM for 5-150 min does not change the frequency of miniature end plate potentials or the quantal content of end plate potentials (Tanabe and Kijima, 1992). Consequently, after 1 DIV, cultures from the same dissociation were divided into three groups. One group served as controls, and the second group was supplemented with AP-5. At 2 DIV, the third group was washed three times in FSS, and then cultures were treated with either 10,5 , or $1 \mu \mathrm{M}$ BAPTA AM in FSS for $30 \mathrm{~min}$. After this loading, the BAPTA solutions were washed out and replaced with culture medium. AP-5treated, BAPTA-treated, and control cultures were grown for 1 subsequent day and analyzed for sprouting. Ten micromolar BAPTA was toxic to most cells showing neuron morphology, and these cultures were not analyzed further. However, at 3 DIV, AP-5- and the $5 \mu \mathrm{M}$ BAPTA-treated cultures showed significant increases compared with controls in neurite sprouting per cell within contacted but not within the isolated cell populations ( $p<$ 0.05 in $5 \mu \mathrm{M}$ BAPTA; $p<0.01$ in AP-5; ANOVA).

\section{Biochemical and immunocytochemical analysis of axonal proteins}

Quantitative Western blots were used to assay protein changes in AP-5-treated and control tectal cultures. For these analyses, protein was harvested at 4 DIV (see Materials and Methods). Typically cultures resulting from the dissociation of $\sim 30$ pairs of stage 60 Xenopus tecta were used for the comparisons, and all Western blotting was run on paired lanes of protein from AP-5-treated and control cultures. Differences between treatment and control lanes for each antibody were examined using a paired $t$ test.

Antibodies to SNAP-25, syntaxin, and the NMDA receptor subunit NR1 were used in these experiments. Anti-tubulin was also used to assay for major changes in cell volume. Each exper- 
A

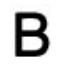

Figure 5. Morphological responses of tectal cells during chronic treatment with AP-5. A, Illustrations of the morphological scoring for neurite ends (white dots) performed on low-density tectal cell cultures at 3 DIV are shown. Enlargements are from the control and AP-5-treated fields shown in Figure 4. The asterisk in the control culture indicates a noncontacted cell with a neurite that sprouted directly from the soma on day 3. $B$, Highdensity cultures provide qualitative evidence that an increase in process outgrowth occurs in the presence of $200 \mu \mathrm{M}$ AP-5. Although increased fasciculation and clustering prohibited meaningful quantification of neurite sprouting and elongation, high-density cultures at $4 \mathrm{DIV}$ were used for collection of protein to be analyzed with immunoblotting. Scale bar, $30 \mu \mathrm{m}$.

iment measured at least three gels from at least three separate dissociations. Our results (Table 1; Fig. 8A) indicated that AP-5 treatment consistently increased the expression of SNAP-25 $(p<$ $0.001)$ but not of syntaxin. NR1 antibody staining was very low compared with the other three antibodies examined, and this caused the quantitative measurement to be either indiscernible from noise or highly inconsistent. No changes were observed in the amount of $\beta$-tubulin. SNAP-25 immunocytochemical staining in neurites of AP-5-treated cultures also appeared more prevalent than in control cultures (Fig. 8B).

\section{DISCUSSION}

We have documented structural effects of NMDA receptor activation in young Xenopus tectal neurons at early stages of synaptogenesis before significant action potential activity or AMPA/KA receptors seem to play any role in the morphological response (Fig. 6). Neither AMPA/KA receptor function nor sodium-dependent action potentials seem to be necessary to produce an NMDA receptor-mediated change in $\Delta\left[\mathrm{Ca}^{2+}\right]_{\mathrm{i}}$ (Figs. $2 A, B, 3 B$, bottom) at the stage when these effects are observed. Furthermore, the NMDA receptor-mediated $\Delta\left[\mathrm{Ca}^{2+}\right]_{\mathrm{i}}$ can be induced by endogenous glutamate release (Fig. $3 A, B$ ) at cell contacts (Fig. $6 A$ vs $C$ ), and it does not reflect a reduced receptor $\mathrm{Mg}^{2+}$ sensitivity (Fig. 2C). Normally in these cultures, NMDA
Control
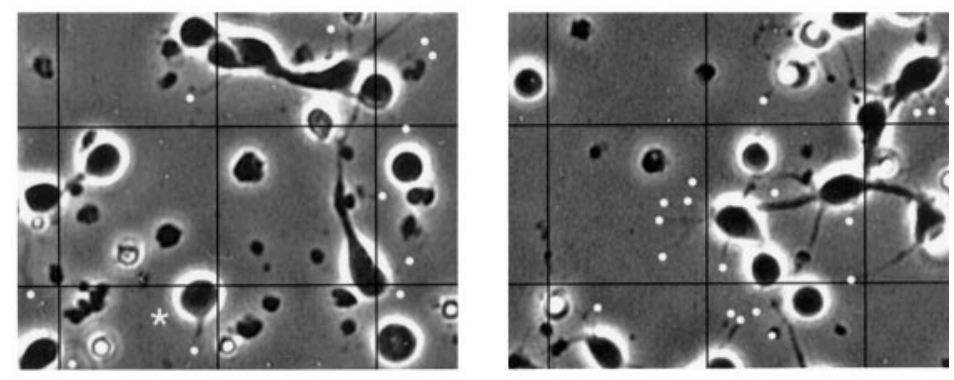

Control

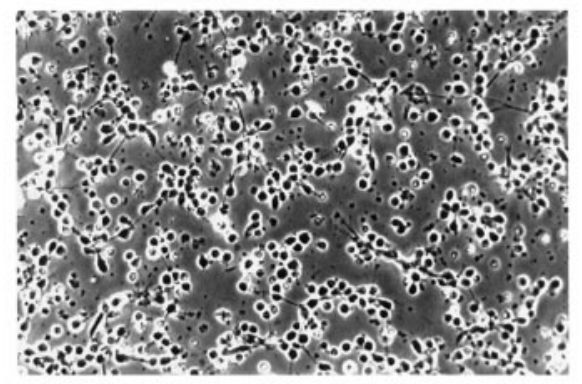

AP5

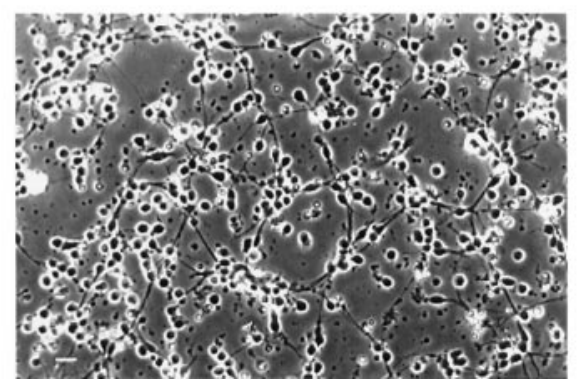

receptor function must suppress both neurite initiation and elongation because NMDA receptor antagonist treatments rapidly increase both parameters (Fig. 6A,B). Furthermore, the effects of NMDA receptor antagonism can be mimicked by loading cells with BAPTA (Fig. 7), indicating that the suppression of motility is probably initiated postsynaptically by $\mathrm{Ca}^{2+}$ influx through the channel of the receptor.

The NMDA antagonist effect is reflected biochemically in increased SNAP-25. At synapses, SNAP-25 is part of the synaptic vesicle docking complex and is essential for vesicle fusion with the presynaptic membrane (Blasi et al., 1993; Sollner et al., 1993). However, in young cultures of neonatally dissociated mammalian neurons and in intact neonatal cortex, SNAP-25 is diffusely distributed within the axoplasm (Osen-Sand et al., 1993). Treatment of cultured neurons with antisense to SNAP-25 transcripts or botulinum toxin, which specifically cleaves the molecule, blocks elongation but not initiation of neuronal processes (Osen-Sand et al., 1993, 1996). These observations on growth inhibition with disruption of SNAP-25, as well as the generally low level of synaptophysin staining in young tectal cultures, suggest that the reliable increase in SNAP-25 in response to AP-5 treatment reflects the association of the molecule with axon growth rather than with an increase in synaptic contacts. This conclusion is 


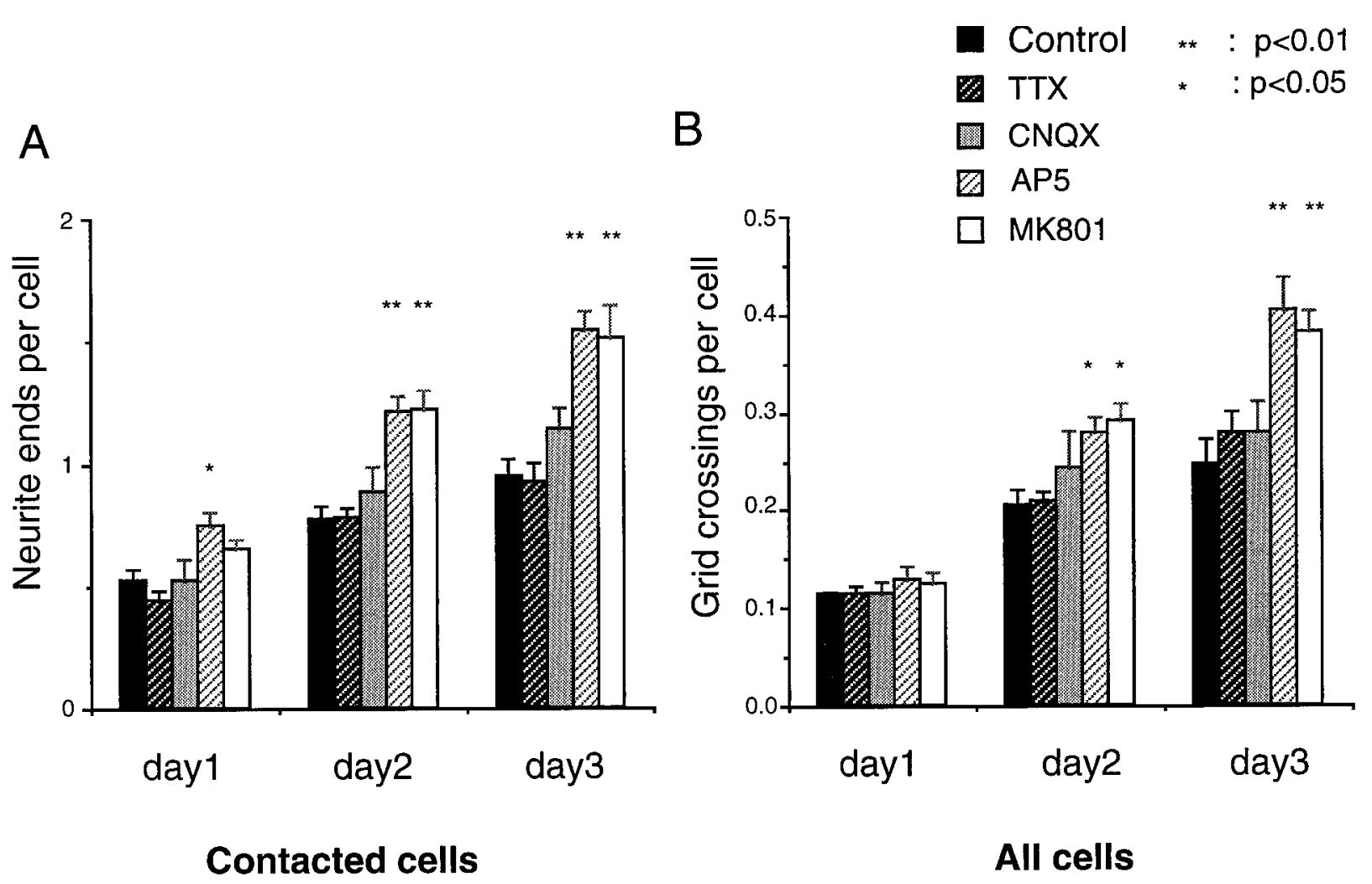

C

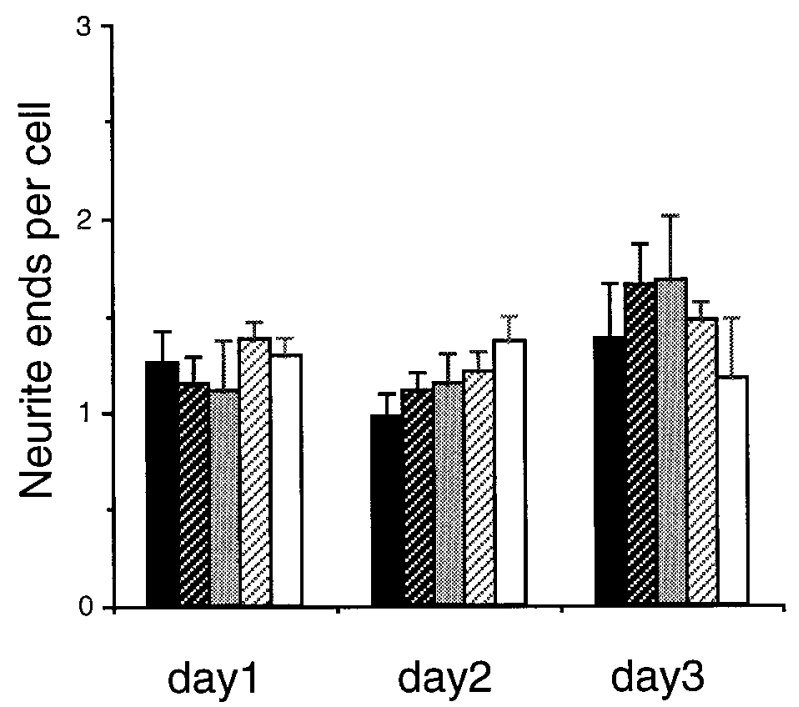

Non-contacted cells

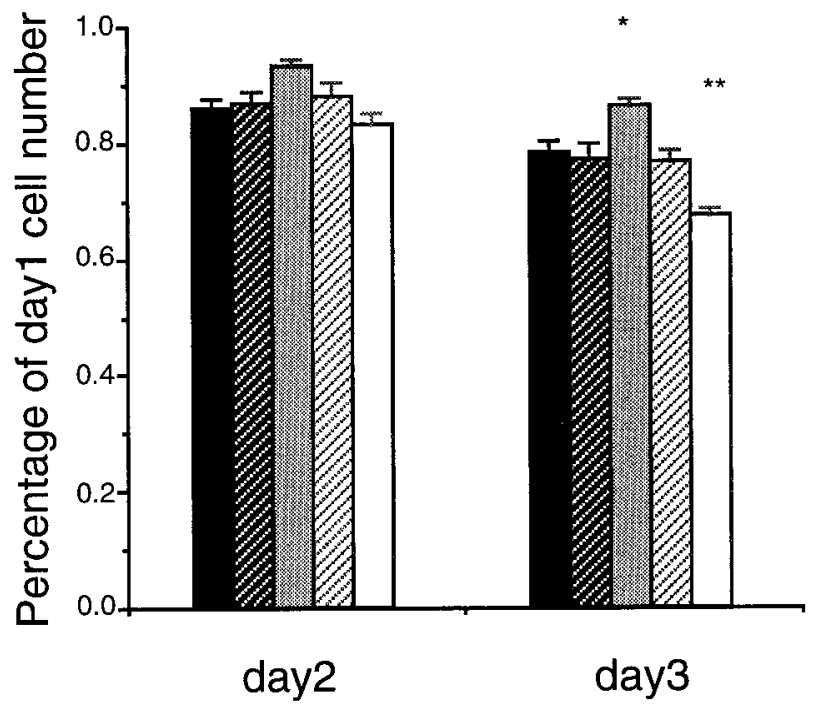

All cells

Figure 6. Quantitative morphological analyses of tectal cells in fields followed for 3 d during chronic treatment with AP-5 (200 $\mu \mathrm{M})$, MK-801 (1 $\mu \mathrm{M}$ ), CNQX $(20 \mu \mathrm{M})$, or TTX $(1 \mu \mathrm{M})$. A, The number of neurite ends of contacted cells normalized to the number of contacted cells in the same fields at 1,2 , and 3 DIV. $B$, The number of neurite grid crossings per number of cells in the fields. $C$, The number of neurite ends in the noncontacted cell populations of the same fields normalized to the number of noncontacted cells in those fields. $D$, Cell survival in the fields. Sister cultures plated at low density were used in all experiments. One field $\left(0.3 \mathrm{~mm}^{2}\right)$ from a minimum of five different cultures was counted for each data point. Error bars represent SEM. All treatments were compared with controls using one-way ANOVA. 


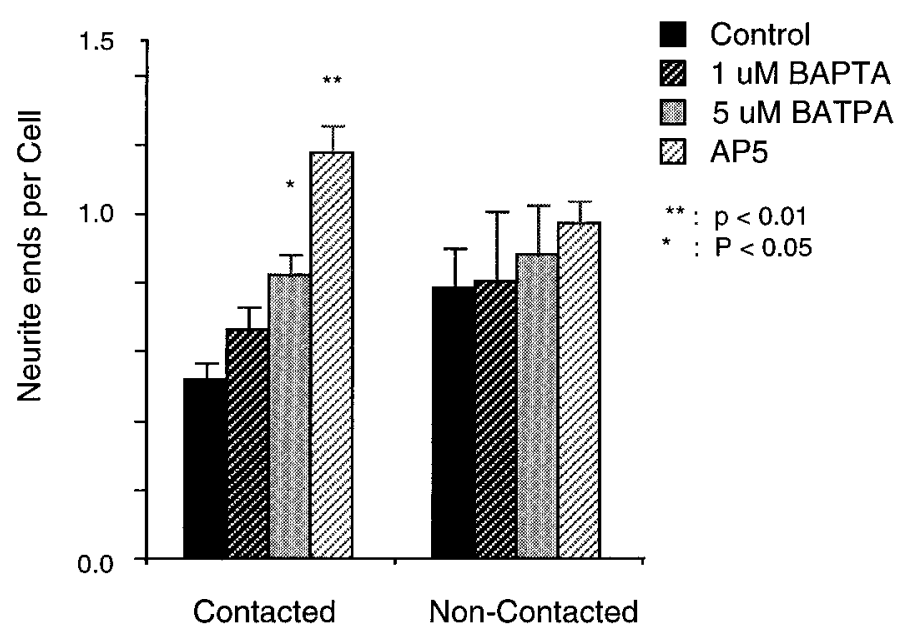

Figure 7. Comparisons of neurite sprouting between tectal cells treated with AP-5 and tectal cells loaded with 1 or $5 \mu \mathrm{M}$ BAPTA AM. Neurite ends in contacted and in noncontacted cells were measured as described in Figure 6. Error bars represent SEMs from counts of five different $\sim 0.3$ $\mathrm{mm}^{2}$ fields. Treatments were compared with controls using one-way ANOVA.

Table 1. Ratio of AP-5 to control integrated OD values

\begin{tabular}{lll} 
& Mean of ratio & SE \\
\hline Tubulin & 1.027 & 0.077 \\
Syntaxin & 1.004 & 0.070 \\
SNAP-25 & $1.463^{*}$ & 0.138
\end{tabular}

$\overline{\text { Integrated OD value of a total of } 11 \text { gels from three independent experiments were }}$ measured by densitometry. The ratio of integrated OD value of the AP- 5 and the control lane in the same gel was used to calculate means and SEs. A paired $t$ test was used to determine the $p$ value by using the difference between the integrated OD values of the AP-5 and the control lanes in the same gel.

$* p<0.001$.

consistent with the unchanging levels of syntaxin, another member of the synaptic vesicle docking complex.

Lacking specific antigenic markers, these studies do not address changes in dendritic sprouting of tectal neurons in response to NMDA antagonists. However, dendritic changes would not be surprising because, in most tectal neurons, axons emerge from dendrites and correlated activity can regulate dendritic morphology of tectal neurons in vivo (Katz and Constantine-Paton, 1988).

We also examined effects of glutamate receptor antagonists and TTX on cell survival in tectal cultures. By the third day of treatment, cultures exposed to MK-801 or CNQX were significantly different from control cultures in the number of surviving cells. The cell loss with MK-801 treatment may reflect a need for $\mathrm{Ca}^{2+}$ influx through NMDA receptors. The noncompetitive blocker MK-801 would be expected to limit this more severely than would the competitive blocker AP-5. More perplexing, however, is the observation that CNQX treatment increased the number of surviving cells in cultures in which it had no effect on neuritogenesis. One explanation is consistent with the hypothesis that synaptic NMDA function induces functional AMPA receptors at young synapses (Liao et al., 1995; Durand et al., 1996; Wu et al., 1996; Isaac et al., 1997). Perhaps, after $3 \mathrm{~d}$ in culture with ongoing NMDA receptor activity, CNQX in the medium rescues some tectal cells with combined AMPA and NMDA receptor function at synapses from excitotoxic cell death. Although delayed AMPA/KA receptor function relative to NMDA receptor function is not supported by our $\mathrm{Ca}^{2+}$-imaging data using specific antagonists in the presence of glutamate, there are two likely explanations for this discrepancy. First, NMDA receptors have much higher affinities for glutamate than do AMPA/KA receptors (Patneau and Mayer, 1990). Whereas a difference in ligand affinity may not produce a functionally detectable effect when cells are swamped with bath-applied glutamate, it could play a significant role in limiting AMPA/KA receptor function at weak, endogenously active, synaptic sites. Second, experiments in chick neuron cultures have recently localized functional NMDA receptors at synaptic sites before AMPA/KA receptors. Nevertheless both receptors are present elsewhere on the plasma membrane (Kiyosue et al., 1997), where they would contribute to responses to bath-applied glutamate.

Previous studies have reported effects of glutamate on neuronal process elaboration, with varied and frequently contradictory results. Thus, increases in spine density can be induced in ferret lateral geniculate neurons by acute application of AP-5 to slices (Rocha and Sur, 1995), but increases in dendritic spines of hippocampal neurons cocultured with entorhinal cortex explants are seen only after multiple glutamate receptors subtypes are blocked (Kossel et al., 1997). In isolated hippocampal neurons, glutamate inhibits dendritic sprouting and elongation acting via non-NMDA receptors (Mattson et al., 1988). Also paradoxical are findings that glutamate applied to slices of hippocampal neurons produces a brief extension of spine-like processes (Smith and Jahr, 1992) and that NMDA receptor blockade applied to larval Xenopus tectal neurons reduces the initiation but not the lifetime of dendritic branches from neurons imaged in vivo (Rajan et al., 1996).

Though the underlying mechanisms are uncertain, axonal responses to glutamate antagonism in the presence of target cells are more consistent than are dendritic responses. Thus, blocking synaptic responses increases retinal axon branching in intact Xenopus tecta (O'Rourke et al., 1994). Similarly, in pontinegranule cell cocultures, the growth of pontine axons is inhibited on a bed of purified cerebellar granule cells, and inhibition can be removed when TTX or AP-5 is applied to the medium (Baird et al., 1992, 1996).

The demonstration of a morphological function for NMDA receptor activity in young tectal neurons without AMPA/KA receptor activation raises the question of what removes the $\mathrm{Mg}^{2+}$ blockade on the NMDA receptors expressed by these cells. There are three nonmutually exclusive possibilities. First, the stretch of young cell membranes mediated by growth cone contacts could unblock the NMDA channel (Paoletti and Ascher, 1994). Second, spontaneous oscillations in membrane potential could serve this function. Third, activation of some other depolarizing receptor system(s) could be fulfilling this function. The tectum in situ contains cholinergic (Gruberg and Udin, 1978), peptidergic (Kuljis and Karten, 1986), and serotonergic inputs and peptidecontaining somata (Debski et al., 1995). In addition, $\sim 13 \%$ of cultured tectal neurons are GABAergic, which is similar to the proportion seen in intact lobes (Rybicka and Udin, 1994). Thus, endogenous peptidergic or aminergic transmission or a depolarizing $\mathrm{GABA}_{\mathrm{A}}$ receptor-mediated current (Owens et al., 1996; Rohrbough and Spitzer, 1996) could produce the necessary depolarization in vivo. In addition, our data support a role for a metabotropic glutamate receptor in producing these depolarizations (Crepel et al., 1994; Miller et al., 1995; Congar et al., 1997) in culture, because glutamate can stimulate an NMDA-mediated $\mathrm{Ca}^{2+}$ response in the absence of AMPA/KA receptor function 
A

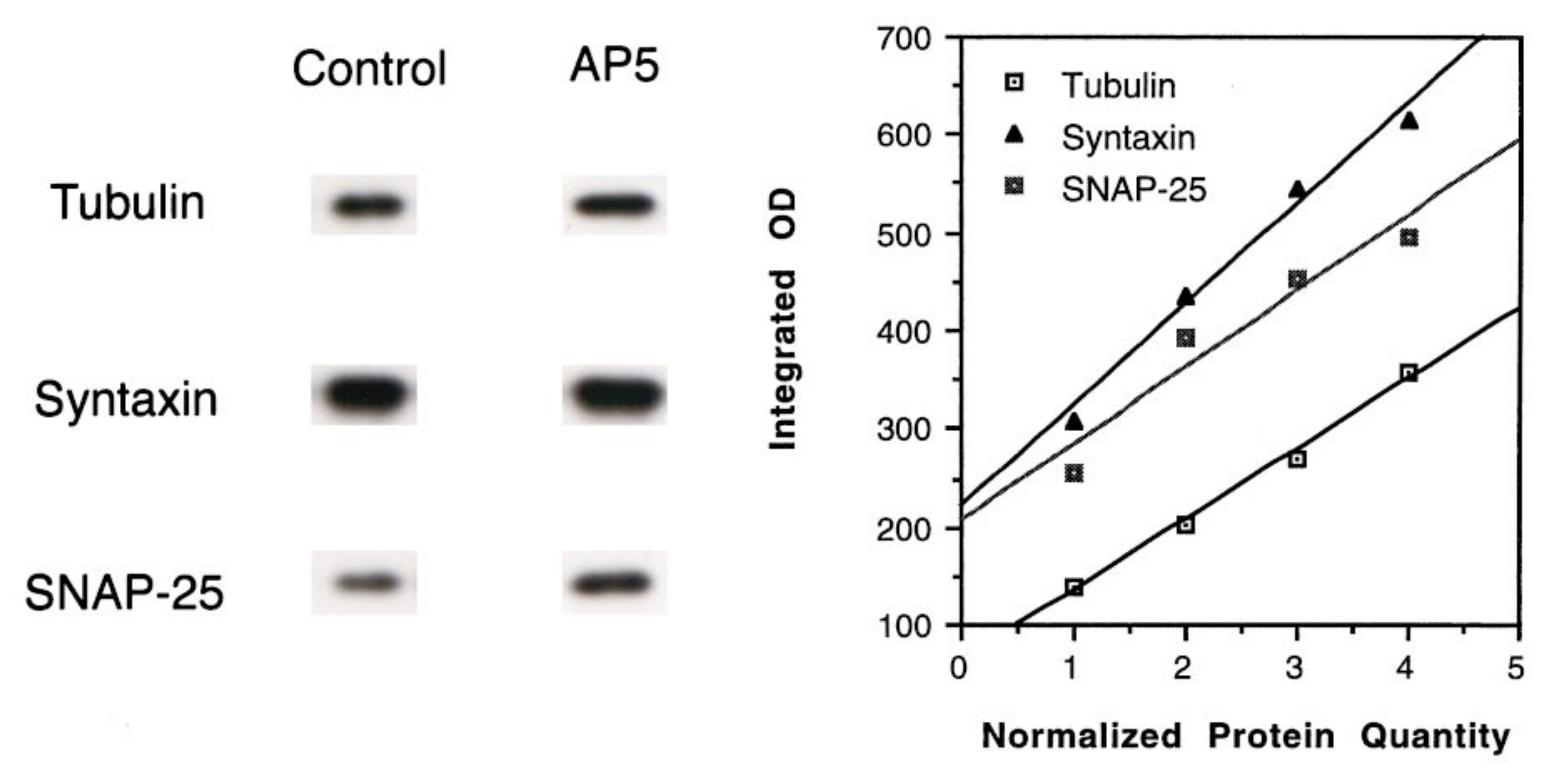

\section{B SNAP-25 Staining}

\section{Control}
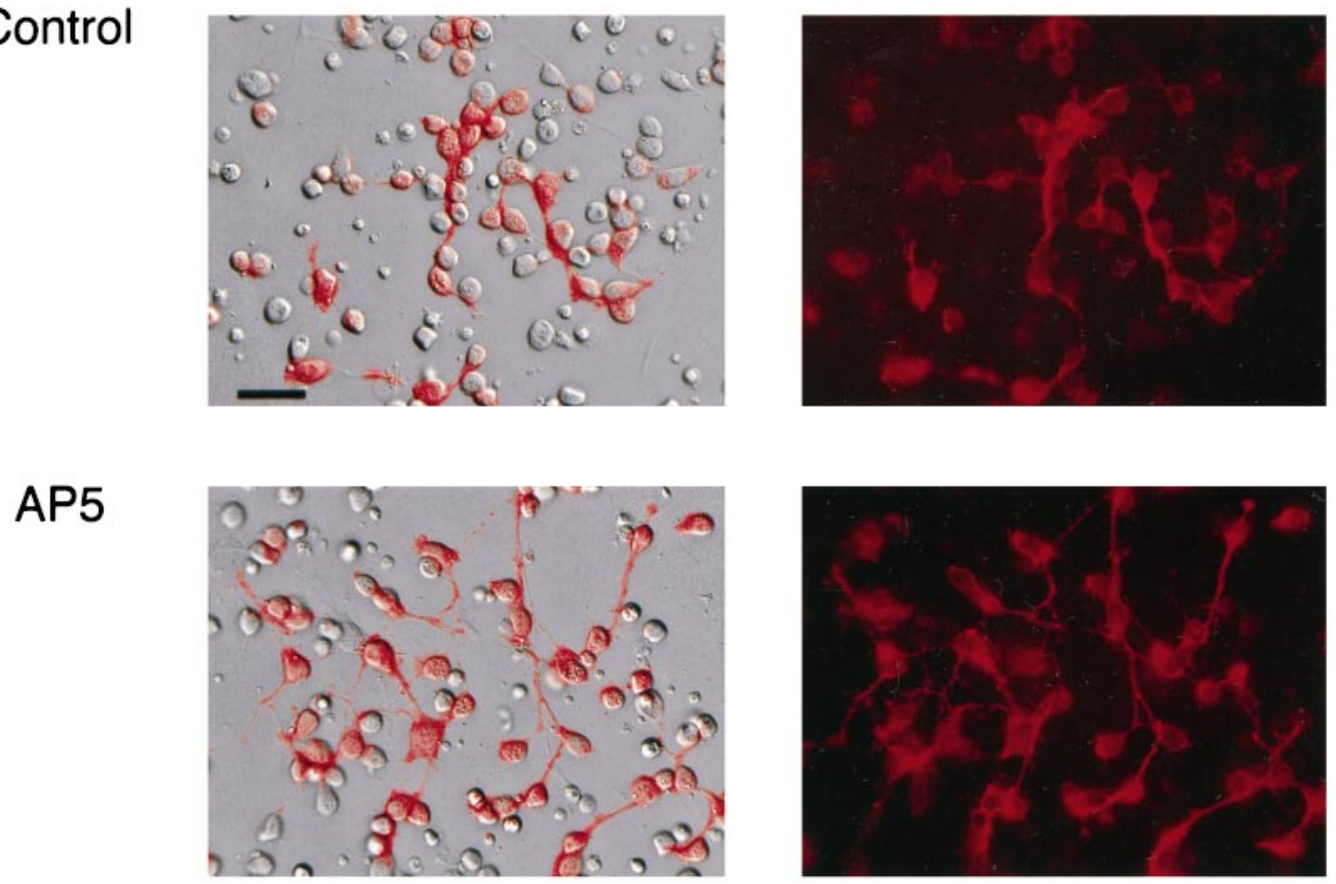

Figure 8. AP-5 blockade increases SNAP-25 levels. $A$, Representative immunoblot showing differences in the amount of SNAP-25, but not of $\beta$-tubulin or syntaxin, in control and AP-5-treated cultures after protein collection at 4 DIV. A single immunoblot is shown here. After transfer of protein, the nitrocellulose paper was cut so that the individual antigens could be isolated by molecular weight range and reacted with their specific antibodies. The plot on the right shows the integrated OD value calibration curves of the same gel, indicating the dynamic range of measuring procedures (from 615 to 139 integrated OD). The OD readings from the bands on the right side are between 220 and 414 . The values fall into the linear range of our detection system. B, SNAP-25 immunostaining. The corresponding DIC (left) and epifluorescent (right) micrographs are shown. At similar cell densities, AP-5-treated cultures show more SNAP-25-positive neurites than do the control cultures. Scale bar, $20 \mu \mathrm{m}$.

and at a time when action potentials do not seem to play a significant role in endogenous glutamatergic activity.

Recent studies in developing nervous system have demon- strated that many young synapses in situ, like contacts in our young dissociated tectal neurons, show functional NMDA receptors before evidence of AMPA receptor function (Liao et al., 
1995; Durand et al., 1996; Wu et al., 1996; Isaac et al., 1997). These electrophysiological studies further suggest that the early NMDA receptor activation may be necessary for inducing AMPA receptor function. The present studies demonstrate a sprouting effect of early NMDA receptor blockade at young neuronal contacts that cannot be mimicked by AMPA/KA receptor blockade, indicating that AMPA receptor currents are not normally active in removing the voltage-dependent $\mathrm{Mg}^{2+}$ block of the NMDA channel at this stage. Assuming these early cultures effectively represent the situation at the onset of synaptogenesis in the intact animal, these data indicate that NMDA receptors can function before action potentials and can play a significant role in shaping CNS circuitry. Indeed, previous studies on early cortical slices suggest such NMDA receptor activation occurs before synapses can be driven by stimulation from the white matter (LoTurco et al., 1991).

Thus, these findings suggest the following addition to the model of silent synapse function generated from electrophysiological studies. During the earliest phases of synaptogenesis, spontaneous glutamate release at young neuron-neuron contacts would activate some NMDA receptors to limit the continued sprouting of axons and possibly dendrites as well. This would favor the accumulation of glutamatergic inputs, and it might also increase the amount of glutamate released from the less-ramified neuron terminals (Yen et al., 1995). Increases in the number and possibly the potency of inputs on a postsynaptic membrane would increase the probability that pure NMDA synapses have spontaneously released glutamate in the cleft when postsynaptic depolarization relieves the $\mathrm{Mg}^{2+}$ block of the receptor. More frequent and larger NMDA receptor currents might, as in the pairing paradigm used in electrophysiological investigation, lead to more AMPA receptor synaptic function. Finally, combined AMPA/NMDA synaptic currents would increase the probability of spike initiation and local circuit spike activity. Thus, an early local function for NMDA receptors in suppressing neurite sprouting and elongation could greatly facilitate the more familiar action potential-dependent, competitive phase of synapse differentiation.

\section{REFERENCES}

Abele AE, Scholz KP, Scholz WK, Miller RJ (1990) Excitotoxicity induced by enhanced excitatory neurotransmission in cultured hippocampal pyramidal neurons. Neuron 4:413-419.

Adler EM, Augustine GJ, Duffy SN, Charlton MP (1991) Alien intracellular calcium chelators attenuate neurotransmitter release at the squid giant synapse. J Neurosci 11:1496-1507.

Alcantara AA, Srinivasan S, Reilein AR, Karr TL (1995) Antibodies directed against microtubule proteins from Drosophila melanogaster cross react with similar proteins in the rat brain. Brain Res 701:47-54.

Baird DH, Hatten ME, Mason CA (1992) Cerebellar target neurons provide a stop signal for afferent neurite extension in vitro. J Neurosci 12:619-634.

Baird DH, Trenkner E, Mason CA (1996) Arrest of afferent axon extension by target neurons in vitro is regulated by the NMDA receptor. J Neurosci 16:2642-2648.

Basarsky TA, Parpura V, Haydon PG (1994) Hippocampal synaptogenesis in cell culture: developmental time course of synapse formation, calcium influx, and synaptic protein distribution. J Neurosci 14:6402-6411.

Bear MF, Kleinschmidt A, Gu QA, Singer W (1990) Disruption of experience-dependent synaptic modifications in striate cortex by infusion of an NMDA receptor antagonist. J Neurosci 10:909-925.

Blasi J, Chapman ER, Link E, Binz T, Yamasaki S, De Camilli P, Sudhof TC, Niemann H, Jahn R (1993) Botulinum neurotoxin A selectively cleaves the synaptic protein SNAP-25. Nature 365:160-163.

Choi DW (1988) Glutamate neurotoxicity and diseases of the nervous system. Neuron 1:623-634.
Cline HT, Tsien RW (1991) Glutamate-induced increases in intracellular $\mathrm{Ca} 2+$ in cultured frog tectal cells mediated by direct activation of NMDA receptor channels. Neuron 6:259-267.

Cline HT, Debski EA, Constantine-Paton M (1987) $N$-methyl-Daspartate receptor antagonist desegregates eye-specific stripes. Proc Natl Acad Sci USA 84:4342-4345.

Congar P, Leinekugel X, Ben-Ari Y, Crepel V (1997) A long-lasting calcium-activated nonselective cationic current is generated by synaptic stimulation or exogenous activation of group I metabotropic glutamate receptors in CA1 pyramidal neurons. J Neurosci 17:5366-5379.

Crepel V, Aniksztejn L, Ben-Ari Y, Hammond C (1994) Glutamate metabotropic receptors increase a $\mathrm{Ca}(2+)$-activated nonspecific cationic current in CA1 hippocampal neurons. J Neurophysiol 72:1561-1569.

Dale N, Kandel ER (1990) Facilitatory and inhibitory transmitters modulate spontaneous transmitter release at cultured Aplysia sensorimotor synapses. J Physiol (Lond) 421:203-222.

Debski EA, Liu Q, Chapman AM (1995) Non-uniform distribution of cellular phenotypes in the optic tectum of the leopard frog. J Comp Neurol 360:671-684.

Durand GM, Kovalchuk Y, Konnerth A (1996) Long-term potentiation and functional synapse induction in developing hippocampus. Nature 381:71-75.

Fletcher TL, De Camilli P, Banker G (1994) Synaptogenesis in hippocampal cultures: evidence indicating that axons and dendrites become competent to form synapses at different stages of neuronal development. J Neurosci 14:6695-6706.

Gruberg ER, Udin SB (1978) Topographic projections between the nucleus isthmi and the tectum of the frog Rana pipiens. J Comp Neurol 179:487-500.

Hahm JO, Langdon RB, Sur M (1991) Disruption of retinogeniculate afferent segregation by antagonists to NMDA receptors. Nature 351:568-570.

Hickmott PW, Constantine-Paton M (1993) The contributions of NMDA, non-NMDA, and GABA receptors to postsynaptic responses in neurons of the optic tectum. J Neurosci 13:4339-4353.

Isaac JT, Crair MC, Nicoll RA, Malenka RC (1997) Silent synapses during development of thalamocortical inputs. Neuron 18:269-280.

Kao JP, Harootunian AT, Tsien RY (1989) Photochemically generated cytosolic calcium pulses and their detection by fluo-3. J Biol Chem 264:8179-8184.

Katz B, Miledi R (1969) Spontaneous and evoked activity of motor nerve endings in calcium Ringer. J Physiol (Lond) 203:689-706.

Katz LC, Constantine-Paton M (1988) Relationships between segregated afferents and postsynaptic neurones in the optic tectum of threeeyed frogs. J Neurosci 8:3160-3180.

Kiyosue K, Kasai M, Taguchi T (1997) Selective formation of silent synapses on immature postsynaptic cells in cocultures of chick neurons of different ages. Brain Res Dev Brain Res 99:201-207.

Komuro H, Rakic P (1993) Modulation of neuronal migration by NMDA receptors. Science 260:95-97.

Kossel AH, Williams CV, Schweizer M, Kater SB (1997) Afferent innervation influences the development of dendritic branches and spines via both activity-dependent and nonactivity-dependent mechanisms. J Neurosci 17:6314-6324.

Kuljis RO, Karten HJ (1986) Substance P-containing ganglion cells become progressively less detectable during retinotectal development in the frog Rana pipiens. Proc Natl Acad Sci USA 83:5736-5740.

Laemmli UK (1970) Cleavage of structural proteins during the assembly of the head of bacteriophage T4. Nature 227:680-685.

Liao D, Hessler NA, Malinow R (1995) Activation of postsynaptically silent synapses during pairing-induced LTP in CA1 region of hippocampal slice. Nature 375:400-404.

LoTurco JJ, Blanton MG, Kriegstein AR (1991) Initial expression and endogenous activation of NMDA channels in early neocortical development. J Neurosci 11:792-799.

LoTurco JJ, Owens DF, Heath MJ, Davis MB, Kriegstein AR (1995) GABA and glutamate depolarize cortical progenitor cells and inhibit DNA synthesis. Neuron 15:1287-1298.

Mattson MP, Dou P, Kater SB (1988) Outgrowth-regulating actions of glutamate in isolated hippocampal pyramidal neurons. J Neurosci 8:2087-2100.

Miller LD, Petrozzino JJ, Connor JA (1995) G-protein-coupled receptors mediate a fast excitatory postsynaptic current in CA3 pyramidal neurons in hippocampal slices. J Neurosci 15:8320-8330. 
Nieuwkoop PD, Faber J (1967) Normal table of Xenopus laevis (Daudin). Amsterdam: North-Holland.

O'Rourke NA, Cline HT, Fraser SE (1994) Rapid remodeling of retinal arbors in the tectum with and without blockade of synaptic transmission. Neuron 12:921-934.

Osen-Sand A, Catsicas M, Staple JK, Jones KA, Ayala G, Knowles J, Grenningloh G, Catsicas S (1993) Inhibition of axonal growth by SNAP-25 antisense oligonucleotides in vitro and in vivo. Nature 364:445-448.

Osen-Sand A, Staple JK, Naldi E, Schiavo G, Rossetto O, Petitpierre S, Malgaroli A, Montecucco C, Catsicas S (1996) Common and distinct fusion proteins in axonal growth and transmitter release. J Comp Neurol 367:222-234.

Owens DF, Boyce LH, Davis MB, Kriegstein AR (1996) Excitatory GABA responses in embryonic and neonatal cortical slices demonstrated by gramicidin perforated-patch recordings and calcium imaging. J Neurosci 16:6414-6423.

Paoletti P, Ascher P (1994) Mechanosensitivity of NMDA receptors in cultured mouse central neurons. Neuron 13:645-655.

Patneau DK, Mayer ML (1990) Structure-activity relationships for amino acid transmitter candidates acting at $N$-methyl-D-aspartate and quisqualate receptors. J Neurosci 10:2385-2399.

Rajan J, Burbank BJ, Cline HT (1996) Soc Neurosci Abstr 485.4.

Rocha M, Sur M (1995) Rapid acquisition of dendritic spines by visual thalamic neurons after blockade of $N$-methyl-D-aspartate receptors. Proc Natl Acad Sci USA 92:8026-8030.

Rohrbough J, Spitzer NC (1996) Regulation of intracellular Cl- levels by $\mathrm{Na}(+)$-dependent $\mathrm{Cl}-$ cotransport distinguishes depolarizing from hyperpolarizing GABAA receptor-mediated responses in spinal neurons. J Neurosci 16:82-91.
Rybicka KK, Udin SB (1994) Ultrastructure and GABA immunoreactivity in layers 8 and 9 of the optic tectum of Xenopus laevis. Eur J Neurosci 6:1567-1582.

Smith SJ, Jahr CE (1992) Rapid induction of filopodial sprouting by application of glutamate to hippocampal neurons. In: The nerve growth cone (Letourneau PC, Kater SB, Macagno ER, eds), pp 19-26. New York: Raven.

Sollner T, Whiteheart SW, Brunner M, Erdjument-Bromage H, Geromanos S, Tempst P, Rothman JE (1993) SNAP receptors implicated in vesicle targeting and fusion. Nature 362:318-324.

Steen P, Kalghatgi L, Constantine-Paton M (1989) Monoclonal antibody markers for amphibian oligodendrocytes and neurons. J Comp Neurol 289:467-480.

Tanabe N, Kijima H (1992) Ca(2+)-dependent and -independent components of transmitter release at the frog neuromuscular junction. J Physiol (Lond) 455:271-289.

Verderio C, Coco S, Fumagalli G, Matteoli M (1995) Calciumdependent glutamate release during neuronal development and synaptogenesis: different involvement of omega-agatoxin IVA- and omegaconotoxin GVIA-sensitive channels. Proc Natl Acad Sci USA 92:6449-6453.

Warton SS, Perouansky M, Grantyn R (1990) Development of GABAergic synaptic connections in vivo and in cultures from the rat superior colliculus. Brain Res Dev Brain Res 52:95-111.

Wu G, Malinow R, Cline HT (1996) Maturation of a central glutamatergic synapse. Science 274:972-976.

Yen L, Sibley JT, Constantine-Paton M (1995) Analysis of synaptic distribution within single retinal axonal arbors after chronic NMDA treatment. J Neurosci 15:4712-4725. 